\title{
Andrew Murray's Theology of Divine Healing
}

\author{
$\mathrm{H}$ M van de Vyver \\ (University of South Africa)
}

\section{ABSTRACT}

\section{Andrew Murray's Theology of Divine Healing}

This article critically discusses Andrew Murray's contention that when Jesus Christ spoke of sickness it was always as of an evil caused by sin and that believers should be delivered from sickness, because it attacks the body that is the temple of the Holy Spirit. He wrote that Christ took upon Himself the soul and body and redeems both in equal measure from the consequences of sin. Murray contrasts low level Christians who enjoy no close fellowship with God, no victory over sin and no power to convince the world with those who are "fully saved", who enjoy unceasing fellowship with God and are holy and full of joy. Justification and sanctification are thus divided as two separate gifts of God where sanctification is obtained through a new and separate act of faith. He taught that sickness is a visible sign of God's judgment and that healing is granted according to the measure of faith of the believer.

\section{INTRODUCTION}

Andrew Murray repeatedly and emphatically confessed his faith in divine healing and his belief that Christians can and should enjoy perfect health in this life. When he lost his voice for more than two years he was forced to cease preaching and working and to seek a cure. He visited prominent doctors in London and, while there, met several faith healers that inspired the development of his own theology on faith healing. He subsequently published a book on the subject with the purpose of illustrating that "according to the Word of God, ... 'the prayer of faith'... is the means appointed by God for the cure of the sick, that this truth is in perfect accord with Holy Scripture, and that the study of this truth is essential for everyone who would see the Lord manifest His power and His glory in the midst of His children” (Murray 1982:5).

Murray's background, the main influences on his theology and the events that lead to the development of his theology of divine healing, are discussed in the following pages in order to answer the following questions: can sickness be viewed as a sign of God's 
judgement? Is healing granted on grounds of the measure of the believer's faith?

\section{CONTEXT AND INFLUENCES}

Andrew Murray and his older brother went to the Netherlands in 1845 to study theology at the Academy of Utrecht. German rationalism influenced the religious atmosphere in the Netherlands at this time. Before Kant the Enlightenment had absolute trust in reason. The nineteenth century scholar, however, started to doubt the ability of human reason and even theology had to base its formulations on a clear conception of the method of reason (Barth 1959:258-259). The Murray brothers found the teaching of the theological professors corrupt and chose to associate themselves with a campus revival group that held Bible study meetings, Sunday schools for the poor and organised gospel outreaches. The activities of this group were ridiculed by the staff and other theological students as being too radical (Choy 2004:43-44).

During one of their vacations, the Murray brothers met Johann Christoph Blumhardt (1805-1880), a German Lutheran theologian. Blumhardt took part in the exorcism of a young girl that suffered from psychosomatic illness in his congregation in Möttlingen in 1842. This event resulted in a revival in Blumhardt's parish, characterised by healings of the sick. He later purchased an asylum in Bad Boll to serve as a Christian retreat, where people came to seek his renowned healing abilities. Although his theology was unsystematic and contained some strange ideas and blatant errors, it was influential on, for example, the work of Karl Barth, who devoted a chapter in his book on Protestant Theology in the Nineteenth Century to Blumhardt. Blumhardt had an EasternChristian view of the person that was concerned with healing the whole person (body and soul). Forgiveness of sins and healing of sickness always went hand in hand in his work (Barth 1959:629639).

Andrew Murray was ordained on his twentieth birthday, 9 May 1848, after which he returned to South Africa to accept his first pastorate. He had an active preaching and visiting schedule until 1879, when he lost his voice. He was forced to stop preaching and undertook a tour of Europe for a change of scenery and to consult medical practitioners. Before his trip he read a book by $\mathrm{W} E$ 
Boardman entitled "The Lord Thy Healer". In a letter to his congregation he wrote from Europe:

I had already given much thought to James 5:14-16 and together with others already made this matter of faith healing a subject of intercession. I had no doubt that the Lord even yet bestows healing on the prayer of faith. Yet it was as though I could not reach that level of faith. Facing this trip to Europe, I felt I had to make a critical decision: should I turn myself over to a doctor to treat me or should I turn exclusively to those who appear to have received this gift of healing from the Lord?

(Choy 2004:143-147).

Upon arrival in London, Murray consulted a famous physician, who prescribed medication and treatments. Shortly thereafter he attended a Christian conference and met Pastor Stockmaier, who was head of an institute for faith healing in Switzerland. Murray confided in Stockmaier his doubts that it may not be God's will that he should be healed and asked whether it would not give God greater glory if he remained silent and served God in another manner. He reasoned that sufferings and trials are a means of grace through which God sanctifies believers. Stockmaier replied that Murray was hampered by the customary views of suffering that most Christians hold and that he should note James' distinction in chapter 5 verses 13 and 14 between suffering and disease. From Murray's diary and correspondence it seems that he then understood that the Bible does not promise that suffering arising from the temptations and trials of life would be taken away. Suffering from the world must serve to bless and sanctify the believer. There is, however, such a promise with regards to sickness and that promise we should claim in prayer:

Suffering that comes upon the Christian from the world outside must serve to bless and sanctify him. But it is different with disease which has its origin within the body, not outside of it. The body has been redeemed. It is the temple of the Holy Spirit. For the believer who can accept it, the Lord is ready to reveal, even in the case of the body, His mighty power to deliver from the dominion of $\sin$.

(Choy 2004:143-147) 
Stockmaier invited him to meetings held by Boardman, whose book on healing he read earlier (Choy 2004:147-148). William E Boardman (1810-1886) was a student at Lane Theological Seminary in Cincinnati for three years after which he appeared on the roll of Presbyterian ministers for nearly twenty years, although he never spent more than two or three years in any one employment. He also wrote "A Higher Christian Life" that enjoyed international success and helped ignite the Higher Life movement. In 1870 Boardman broke all ecclesiastical ties and started organising "Conventions for Holiness” throughout America. In 1872 he joined Pearsall Smith's meetings for the propagation of the Higher Life in London. One such meeting in Oxford in 1874 was particularly effective, so that the Higher Life teaching and interest therein spread through Britain and Europe, particularly in Germany.

Pearsall Smith's wife, Hannah Whitall Smith, was at least as influential as her husband. Her writing career spanned thirty years and she regularly preached at packed Holiness conventions. In her most well-known book, "The Christian's Secret of a Happy Life”, which had sold more than two million copies at its thirty seventh printing in 1984, she writes that the chief characteristics of the Higher Life are entire surrender to and perfect trust in the Lord, which results in victory over sin and inner peace. She remained a Quaker all her life and held a doctrine of Quietist Perfectionism with a strong emphasis on universal salvation. The Higher Life movement reached its culmination through the work of the Smiths and developed into the Keswick (Victorious Life) movement in Britain and in the "Heiligungsbewegung" in Germany.

In the last years of his life Boardman focused on healing the sick. The Bethshan house was opened in London to accommodate the patients who came to him for help. He joined with the Canadian pastor A B Simpson, founder of the Christian and Missionary Alliance, in speaking at the 1885 Bethshan Conference on Holiness and Healing in London. This conference is regarded by many as a turning point in the origins of the modern Pentecostal movement (Warfield 1974:216-288).

A B Simpson's personal spiritual journey and ministry embodied for some critics all of the major aspects of the spiritual atmosphere of evangelical Protestantism in the second half of the nineteenth century. Simpson added an expectation of divine healing 
to his theology after two significant events in his life. First, he read Boardman's 'The Higher Christian Life' that persuaded him of the need to enter a "higher and deeper" life of full sanctification and, second, he was prayed for by Charles Cullis in 1881. He visited Bethshan and established his own healing home in the United States. He also found the Christian Alliance, which proclaimed a "gospel of full salvation". One of the cornerstones of its teaching held that to use medicine is a denial of faith that God could heal sickness supernaturally. Simpson was publicly condemned when three young missionaries to Sudan, influenced by him, died in 1890 when they refused to take medicine ${ }^{1}$. Despite the criticism, healing homes continued to be established and in 1887 a troubled physician told a Y.M.C.A. audience in Utica, New York "that twenty-five faithcure establishments have sprung up in this country within the past few years" ${ }^{2}$.

Murray asked to be admitted as a patient at Bethshan and stayed there for three weeks. In a letter to his congregation he wrote:

I imagine you may wonder why it was necessary to enter a special place and remain there for so long. You may think that surely the prayer of faith is a matter of a moment, just like the laying on of hands or the anointing with oil of which James speaks. Quite true. Yet in most cases, time is needed in order to learn what God's Word actually promises and to ... understand what the cause and purpose of the disease really are, and what are the conditions and the meaning of healing. Remaining in such a home with all its surroundings helps to make this matter plain and to strengthen faith... Morning by morning sixteen or eighteen of us who sought healing gathered around the Word of God and were instructed as to what still remained in us to prevent us from appropriating the promise. We were taught what there was in Scripture to encourage us to faith and complete

1 Hudson, N 2003. Early British Pentecostals and their relationship to health, healing and medicine. Available from: www.apts.edu/ajps/03-2/03-2NHudson.pdf. [Accessed 30 November 2007].

2 Cunningham, R J 1974. From Holiness to Healing: The Faith Cure in America, 1872-1892. Available from: http://0www.jstor.org.oasis.unisa.ac.za. [Accessed 30 November 2007]. 
surrender. I cannot remember that I ever listened to expositions of the Word of God in which greater simplicity and a more glorious spirit of faith were revealed, combined with heart-searching application of God's demand to surrender everything to Him.

(Choy 2004:143-150)

During his stay, Murray's voice was healed and he never experienced similar problems again. He returned to his preaching schedule and healing the sick was part of his ministry from then on, although not always with success (Choy 2004:143-150). He also published a book on divine healing, the preface to which reads as follows:

The publication of this work may be regarded as a testimony of my faith in divine healing. After being stopped for more than two years in the exercise of my ministry, I was healed by the mercy of God in answer to the prayer of those who see in Him 'the Lord that healeth thee' (Ex. 15:26). "This healing, granted to faith, has been the source of rich spiritual blessing to me. I have clearly seen that the Church possesses in Jesus, our Divine Healer, an inestimable treasure, which she does not yet know how to appreciate. I have been convinced anew of that which the Word of God teaches us in this matter, and of what the Lord expects of us; and I am sure that if Christians learned to realize practically the presence of the Lord that healeth, their spiritual life would thereby be developed and sanctified. I can therefore no longer keep silence, and I publish here a series of meditations, with the view of showing, according to the Word of God, that 'the prayer of faith' (James 5:15) is the means appointed by God for the cure of the sick, that this truth is in perfect accord with Holy Scripture, and that the study of this truth is essential for everyone who would see the Lord manifest His power and His glory in the midst of His children.

(Murray 1982:5) 


\section{FULL SALVATION}

The doctrine of Christian Perfection developed through John Wesley's teaching of "perfect love" as one of the distinguishing factors of Methodism and was first promulgated in the United States by Charles Finney around 1830. Perfectionists declared that beyond the "new birth" of justification at conversion, there lay the "higher life" of sanctification, which is passed on to the believer together with the baptism of the Holy Spirit. This "second blessing” brings complete and instantaneous purification from sin and perfect holiness toward God.

John Wesley (1703-1791) developed a doctrine of sanctification that he called "Christian perfection", "perfect love" (1 John 4:18), "entire sanctification", or "full salvation”. Different books from the Catholic and Anglican mystical traditions, for example William Law's Treatise on Christian Perfection (published in 1726), influenced the development of his ideas. He taught that as Matthew 5:48 commands perfection ("Be ye therefore perfect, even as your Father which is in heaven is perfect"), it must be attainable in this life. This perfection is not absolute, but is relative in that it consists of freedom from wilful (conscious), voluntary sinning against known divine law. A "perfect" Christian is therefore still subject to errors and involuntary transgressions. He nevertheless called the sanctified Christian sinless and urged all Christians to strive for this perfection ${ }^{3}$.

A similar tendency developed in the nineteenth century, partly as a result of the increasing dissolution of Calvinism in America and advanced by Boardman's book on "The Higher Christian Life" that proclaimed perfection a Christian duty and an attainable ideal. The trend moved away from social involvement and toward pietism and Pentecostalism. The most distinctive expression of the nineteenth century perfectionism was "healing by faith". This is clearly revealed in the way that the ministries of three of the leading practitioners of faith healing, Charles Cullis, Boardman and Simpson, married perfectionism and faith healing.

3 Combs, W W 2001. The disjunction between justification and sanctification in contemporary evangelical theology. Available from: http://www.dbts.edu/journals/2001/Combs.pdf. [Accessed 30 November 2007]. 
Boardman acquired the ideas for his book under Methodist influences in a frontier settlement. The introduction to the book states that much has been written about "perfection" and "sanctification" in conflict with the Bible and church standards, and so many have made shipwreck, and run wild with it, that "grim and ghastly errors rise up to frighten them from the very first step". He therefore aims to show what is acceptable by "the Bible and the standards". Warfield and other critics agree that it is not a good book and highlighted the incorrectness of its historical illustrations, the vagueness and ambiguity of its doctrinal statements and the inconsequence of its arguments. The book nevertheless sold more than a hundred thousand copies in the United States and United Kingdom. Its appeal probably lay in the fundamentally Christian tone as it exalted Christ and faith (Warfield 1974:217-238) ${ }^{4}$.

Boardman teaches that from the moment we accept Christ for sanctification we receive in Him freedom from all conscious sinning and at the same time absolute assurance that He will progressively cleanse our "heart and life" in his time and manner from all sin. It is an ingenious combination of a constant sense of freedom from sin in Christ with a constantly increasing deliverance from sin by Christ (Warfield 1974:238-239).

According to Boardman, when we have Christ Himself and not merely things from Him, we have everything, are perfect, and there is no more room for growth. We are "uplifted" by the Spirit into Christ and He is available "in all his fullness, the Fullness of God in us". It is therefore not possible for us to be sick or weak or sinful in any way, for this is incompatible with the fullness of life we receive in Christ (Warfield 1974:217-238).

Boardman's influence is evident in the chapter that Murray devotes to full salvation in his book on Divine Healing. He divides Christians into two classes: the low level, poor Christians enjoy no close fellowship with God, no victory over sin, no power to convince the world, while those who are fully saved enjoy unceasing fellowship with God and their lives are holy and full of joy. Murray calls the lower class Christians to repent, believe that God can blot

4 Boardman, W E. A Higher Christian Life. Available from: http://online. auc-nuc.ca/alliancestudies/boardman/Higher_tptc.htm [Accessed 30 November 2007]). 
out the sin of their unbelief and to claim their full salvation with confidence (Murray 1982:135-143). "He is able to save to the uttermost” (Murray 1982:92). Murray addressed his readers as follows: "I suppose there are not a few Christians here who have got 'full salvation'; but perhaps more than half those present have not got it” (Murray 1982:63).

Murray is identified as one of the leaders of the Keswick movement in a series of meetings, known as the Northfield Conventions, in the United States in the 1890s. Other leaders include D L Moody, F B Meyer, H W Webb-Peploe, G Campbell Morgan, A B Simpson and A J Gordon. Sloan's approved history of the movement also claims Pearsall and Hannah Whitall Smith as two of Keswick's earliest leaders ${ }^{5}$.

The first Keswick Convention took place in June 1875 in the Northwestern British town of Keswick and consisted of a few hundred attendees gathered for a program of Bible studies, speeches and prayer meetings focused on "practical holiness".

In his book "The Deeper Christian Life”, Murray talks about “a conviction for sanctification". Just as the unconverted man needs a conviction before conversion, the "dark-minded" Christian need conviction "before, and in order for sanctification" to take place. Without this conviction, under which such believers must break down, there is no hope that they will come to a real insight with regards to the spiritual blessedness of His presence, and the fullness of His power and love. This second conviction is needed because of the Christian's sinful life of doubt, and temper, and lack of love ${ }^{6}$.

In "The Two Covenants" Murray writes that Christ, the Mediator of the New Covenant, has been made "both righteousness and sanctification” for us (1 Corinthians 1:30). The righteousness is as a preparation for sanctification or holiness. Christ prayed to the Father: "Sanctify them in the truth; your word is truth... And for their sake I consecrate myself, that they also may be sanctified in truth" (John 17:17 and19). In terms of the New Covenant the very

5 Combs, W W 2001. The disjunction between justification and sanctification in contemporary evangelical theology. Available from: http://www.dbts.edu/journals/2001/Combs.pdf. [Accessed 30 November 2007].

6 Murray, A. The Deeper Christian Life. Available from: www.ccel.org/ ccel/murray/deeper.html. [Accessed 30 November 2007]. 
nature of the new man is holy in Christ and after God. We shall know the truth of this as we believe it, receive it, yield ourselves to it and come nearer to God. Our holiness will be drawn forth and revealed in fellowship with God, its source. For this purpose the Holy Spirit, the Spirit of Holiness, has been given in our hearts. Paul said that "God chose you as the firstfruits to be saved, through sanctification by the Spirit and belief in the truth" (2 Thessalonians 2:13). If we know, honour and trust The Holy Spirit we will learn and experience that the sanctification of the Holy Spirit is our covenant right. If we believe this, we can live holy lives ${ }^{7}$ (Murray 1982:6 and 25).

Driven by real desire for holiness and dissatisfaction with the quality of their spiritual experiences many Christians have looked to Wesley, the Keswick and Higher Life teachers in a search for legitimate experiences beyond their conversion that could deliver them from their daily struggles. They search for a happy, higher, victorious life where one can be at rest from temptation. The message of the teachers from whom they seek answers, is, however, flawed, as it makes an unbiblical distinction between justification and progressive sanctification. Justification and progressive sanctification cannot be divided in such a way that a believer may have one without the other ${ }^{8}$.

Although it is true that we have both justification and sanctification only in Christ and that we have Christ only by faith, it is impossible to divide Christ and have Him as our righteousness while not at the same time having Him as our sanctification. The Bible, in particular Romans 6 and 7, joins justification and sanctification indissolubly together. At most it is two stages of the one salvation secured by faith in Christ. It is precisely this division that the Holiness Movement is insisting upon as a pure statement of the Wesleyan doctrine of the successive attainment of righteousness and holiness by separate acts of faith (Warfield 1974:228-234).

7 Murray, A. The Two Covenants. Available from: www.ccel.org/ $\mathrm{ccel} /$ murray/covenants.html [Accessed 30 November 2007].

8 Combs, W W 2001. The disjunction between justification and sanctification in contemporary evangelical theology. Available from: http://www.dbts.edu/journals/2001/Combs.pdf [Accessed 30 November 2007]. 
This separation of sanctification and justification are repeatedly contradicted by the Scriptures. The sixth chapter of the letter to the Romans, for example, was written for the explicit purpose of making it clear that justification and sanctification are indissolubly bound together. Paul answers the question, "Shall we continue in sin, that grace may abound?” by emphatically stating that justified believers are not able to "continue in sin" because they have "died to sin". This means that the justified person is no longer under the dominion of sin. To "continue in sin", leading a lifestyle of sin is therefore no longer possible. The believer is not sinless or immune to temptation, but it does mean that he or she is no longer a slave of sin and has a fundamental disposition in life toward holiness. The contrast in Romans 6 is between the actual experience of all regenerated, justified believers, who are slaves to righteousness and the unbelievers, who are slaves to sin. This is not a second work of grace but is a death that takes place at conversion (baptism) and brings about a transformation so enormous that it can be described as death and resurrection. Believers are buried with Christ by baptism and arise to a new life in Christ just as Christ was raised up from the dead by the glory of the Father ${ }^{9}$.

In justification the guilt and power of sin is removed and the believer is declared righteous, but sanctification deals with the corruption of our nature as a result of sin. Progressive sanctification, that "gracious operation of the Holy Spirit, involving our responsible participation, by which he delivers us from the pollution of sin, renews our entire nature according to the image of God, and enables us to live lives that are pleasing to him", will not be totally accomplished in this life. Dying with Christ and living with Christ are integral elements in one inseparable salvation (Warfield 1974:356).

In other words, sanctification begins at the moment of conversion when the power of $\sin$ is destroyed. Thereafter progressive sanctification is a process in which the sinful tendencies in the believer are increasingly weakened and mortified and holy tendencies are increasingly awakened and strengthened. Sanctification is not complete in this life and neither is it automatic. It is,

9 Combs, $\mathrm{W} \mathrm{W}$ 2001. The disjunction between justification and sanctification in contemporary evangelical theology. Available from: http://www.dbts.edu/journals/2001/Combs.pdf [Accessed 30 November 2007]. 
however, inevitable as the regenerated part of the believer overcomes sin through the sanctifying Spirit of Christ ${ }^{10}$.

In the teachings of Boardman, Smith and Murray it does not sound like sanctification that the Christian receives when he accepts Christ for sanctification, it sounds more like mere peace or happiness. Warfield comments that this uncovers to us the underlying motivation of the whole Higher Christian Life movement: "It is preoccupied with the pursuit of happiness and tends in many ways to subordinate everything to it." A common fundamental point in all of the Higher Life movements is that justification and sanctification are divided as two separate gifts of God. Sanctification is taught as being obtained through a new and separate act of faith; not by the same act of faith by which justification is obtained, but by an act of faith exercised specifically for the purpose of sanctification. Upon this act of faith sanctification comes immediately, completely and all at once. They all state this complete sanctification does not, however, bring freedom from all sin. It only frees the believer from conscious sinning and is not a stable condition, but must be maintained moment by moment. It may be readily lost and often is lost, but can also be repeatedly recovered in an instant ${ }^{11}$.

\section{THE SANCTIFIED BODY}

Murray's view of the human body is discussed in several chapters in his book on divine healing. He believed that the human person has a twofold nature. He or she "is at the same time spirit and matter, heaven and earth, soul and body". On the one hand, human beings are children of God and on the other they are doomed to destruction as a result of the Fall. Sin in people's souls and sickness in their bodies testify to the right which death has over them. Christ, who took upon Him a human body and soul, redeems both in equal measure from the consequences of sin. Some believers seek after holiness, but only for the soul and spirit. They forget that their

10 Combs, W W 2001. The disjunction between justification and sanctification in contemporary evangelical theology. Available from: http://www.dbts.edu/journals/2001/Combs.pdf [Accessed 30 November 2007].

11 Althouse, P 1995: Wesleyan and Reformed Impulses in the Keswick and Pentecostal Movements. Available from: http://www.pneumafoundation.org/ article.jsp?article=/Keswick-PAlthouse.xml [Accessed 30 November 2007]. 
bodies are the members of Christ (1 Cor 6:15) (Murray 1982:3-4 and 20).

Murray continued that the physical human body, governed by the spirit, is capable of being transformed by the power of the Spirit of God to manifest therein His power. The body, as God's temple, can be set free from the domination of sickness, sin, and Satan. What has to happen first, however, is that the person must be fully subject to and crucified with Christ, renounce all self-will and independence and desire nothing other than being the Lord's temple. It is in anticipation of that day when regenerated humanity, forming the body of Christ, shall be truly and visibly the temple of the living God, that the Lord attaches such a great importance to the indwelling and sanctification of our bodies, down here, by his Spirit. Murray then used the example of the healing of the paralysed man in the Gospels to support his theory:

The Lord Jesus begins by saying to him, "Thy sins be forgiven thee", after which He adds, "Arise and walk". The pardon of sin and the healing of sickness complete one the other, for in the eyes of God, who sees our entire nature, sin and sickness are as closely united as the body and the soul.

(Murray 1982:3-4 \& 20)

We tend to think that sin - justly condemned by God - belongs to the spiritual domain, while sickness is only a part of the present condition of our nature and have nothing to do with God's condemnation. Christ warned the disciples of many sufferings to come and taught that every believer will have to bear his and her cross, but when He spoke of sickness it was always as of an evil caused by sin and Satan, and from which we should be delivered. Sickness should be healed because it attacks the body, which is become the dwelling place of the Holy Spirit. Christ "healed all that were sick, that it might be fulfilled which was spoken by Esaias the prophet, saying: Himself took our infirmities and bore our sicknesses" (Mt 8:16, 17) and to make known the love of the Father. In his deeds, teaching and in the work of the apostles, pardon and healing were always found together. Either forgiveness or healing was at times more prominent. Sometimes it was healing which prepared the way for forgiveness, at other times forgiveness 
preceded the healing, which sealed the pardon (Murray 1982:4, 1719 and 20).

Murray contended that at the time of Christ it was more difficult for the Jews to believe in the pardon of their sins than in divine healing, but in Murray's time it was the other way around. The Christian Church has heard so much of the preaching of forgiveness that it easily receives this message, but divine healing is rarely spoken of and not many believers have experienced it. Healing is no longer given today in the way that Christ healed the multitudes without any previous conversion. Now it is necessary to begin by confession of sin and the purpose to live a holy life and that is why people find it difficult to believe in healing. "Good health is too often for them only a matter of personal comfort and enjoyment which they may dispose of at their will, but God cannot thus minister to their selfishness". Christ is Saviour both of the soul and of the body granting pardon and healing so that believers may serve Him and be used by Him.

We have been made partakers of Christ's redemption in order to make us holy. Healing accompanies the sanctification by the Spirit to either lead the sick one to be converted and to believe (Acts 4:29, $30 ; 5: 12,14 ; 6: 7,8 ; 8: 6-8)$ or to constrain believers to renounce sin and to consecrate themselves to God (1 Cor 10:31; James 5:15, 16; Heb 12:10) (Murray 1982:29).

Murray states that sickness is a consequence of and a visible sign of God's judgment. God permits sickness because of sin, to show us our faults, to chasten us, and purify us. In James 5:15, 16, for example, the pardon of sins and the healing of sickness are closely united. Sins that have not been repented from present an obstacle to the prayer of faith and the sickness may soon reappear. The first letter to the Corinthians indicates that their inappropriate behaviour at the Lord's Supper is a reason why many of them are weak and sick (1 Cor 11:30). God has a distinct purpose in permitting the chastisement and "makes use of Satan as a wise government makes use of a jailer" - as soon as they confess and forsake their sins and consecrate themselves to the Lord, the chastisement will no longer be needed and they can share in the redemption of Christ who has conquered Satan and removed us from Satan's domination by bearing our sins and our sicknesses (Murray 1982:39-41 and 58). 
In contrast to the teachings of Murray, Boardman and other Higher Life teachers maintain what is written in Romans 8:22-25, namely, that together with the whole of creation, we wait patiently for the redemption of our bodies. Our bodies have not yet been made perfect and will not be made perfect until the return of Christ. Sickness is not inextricably linked to the sin of any individual person or group of people and not every sickness could be healed through prayer or faith. Paul himself recommended that Timothy should drink wine for his digestive problems, instead of offering to pray for him or instructing him to pray for healing. The full redemption of our bodies, which would include total health and healing, is part of our eschatological hope. Linking all sickness with personal sin will mean that one would always play the role of Job's comforters ${ }^{12}$.

Nowhere in the Bible does it teach that it is always the sin of that individual believer that resulted in the illness, nor that God wants everyone healed. In humility we should resist the temptation to simplify the matter by providing conclusive answers as such answers will be at least partially untrue. Sickness and suffering is a mystery. Reconciling evil in the world with the will of a compassionate God lies beyond human understanding (MacNutt 1977:93).

The instructions in James 5:14-16 and Paul's comment in 1 Corinthians 11:29-30, neither of which aims to provide a complete theology on healing, form the main Scriptural reference for the theology of faith healing. Other passages in the Bible are conveniently ignored. Matthew 14:14, for example, clearly states that Jesus healed the sick in the crowd that followed Him, because He had compassion on them. In Matthew 25:36 those who will inherit the kingdom will be those who visited, not healed, the sick during their life on earth. In Paul's letters we read about his fellow workers Epaphroditus (Phil 2:26) and Erastus (2 Tim 4:20) who were ill while with him.

\section{ACCORDING TO THE MEASURE OF YOUR FAITH}

As a further condition for healing, Murray stated that without faith no one can be healed (Murray 1982:15).

12 Hudson, N 2003. Early British Pentecostals and their relationship to health, healing and medicine. Available from: www.apts.edu/ajps/03-2/03-2NHudson.pdf [Accessed 30 November 2007]. 
Murray argues that as we increasingly experience personal sanctification by faith, we will also increasingly experience healing by faith as these two doctrines go hand in hand, to testify to the world what it means to be redeemed. The more the Holy Spirit lives and acts in believers, the more miracles will multiply in the body. Although he recognises that medicine also comes from God, Murray asks his readers whether they will "follow the way of natural law" with the unbelievers, or will they choose "the way of faith" and receive healing from God. One of the principal laws of the kingdom of heaven is that God can only bless us to the extent that we yield to his divine working, in proportion to the faith that we have (Murray 1982:6-7 and 13).

Murray's statement that God can only bless us to the extent that we yield to his divine working and in proportion to the faith that we have, sounds like the familiar teaching of Pelagianism, which states that Christ is dependent in his action on our pleasure and that He works and can work only when we release Him for working. If it is true that He can do nothing unless we believe, then it is not Christ who regulates our activities and thereby sanctifies or heals us, but we who regulate His activities and so secure our own sanctification or healing. The initiative and decisive action is therefore in our hands (Warfield 1974:246 and 291).

Murray also exhorts his readers that they must not only surrender to Christ, they must also abide in Him, because "if you are not willing to sacrifice time to get alone with Him, and give Him time every day to work in you, and to keep up the link of connection between you and Himself, He cannot give you that blessing of His unbroken fellowship" and "close, personal, actual communion with Christ is an absolute necessity for daily life" (Murray 1982:70). In other words, not only is God helpless to work on and in us unless we place ourselves in his hands, He is equally helpless to keep us in His hands when He has undertaken the work.

\section{CONCLUSION}

It seems that some Pentecostal influences with an anti-intellectual bias have tended to preach universal healing without balance, but with great effect, while more established churches, proud of their intellectual tradition, have either neglected to preach on healing or have done so with great caution but little power. We need preachers that are courageous in faith, responsible in their interpretation of 
Scripture and true to reality to serve the sick in our churches (MacNutt 1977:92).

It is not difficult to imagine how much guilt, pain, fear and alienation a theology such as Murray's has caused countless believers. As C S Lewis commented in “A Grief Observed”, after his wife died of cancer, "we are tempted to see God as a sadist if we think that he is the one willing the sickness". Such a distorted view of God is in contrast to the image of a loving Father that Jesus presents: "If you then, who are evil, know how to give good gifts to your children, how much more will your Father who is in heaven give good things to those who ask him!” (Matthew 7:11). What mother or father would choose cancer as a way to discipline their child? Inevitably the sick person would ask: what kind of God, what kind of love is it that would want to see me suffer like this? He or she will experience God as punishing and distant and will be unable to trust such a relationship (MacNutt 1977:104-105).

For many adherents of "Higher Life" ideas, being sick may be merely an interruption of their enjoyment of life, but in large parts of the world disease is due to circumstances beyond their control. Clean water, adequate nutrition, healthy relationships and safe living conditions are usually requirements for people to be healthy. To pray for their healing would often mean praying that unjust economic situations and corrupt political regimes be changed. We should therefore not stop praying for the sick, but should realise that the struggle against sickness will continue as long as we have to pray, "Thy Kingdom come on earth as it is in Heaven""

\section{Consulted literature}

Barth, K 1959. Protestant Theology in the Nineteenth Century. London: SCM Press Ltd.

Choy, L 2004. Andrew Murray's authorized biography. Fort Washington: CLC Publications.

Lewis, C S 2001. A Grief Observed. New York: HarperOne.

MacNutt, F 1977. The Power to Heal. Notre Dame: Ave Maria Press.

Murray, A 1982. Divine Healing. Springdale: Whitaker House.

13 Hudson, N 2003. Early British Pentecostals and their relationship to health, healing and medicine. Available from: www.apts.edu/ajps/03-2/03-2NHudson.pdf [Accessed 30 November 2007]. 
Wakefield, G (ed) 1983. A Dictionary of Christian Spirituality. London: SCM Press Ltd.

Warfield, B B 1974. Perfectionism. Philadelphia: The Presbyterian and Reformed Publishing Company.

Withall Smith, H 1984. The Christian's Secret of a Happy Life. Old Tappan: Fleming H. Revell Company.

\section{Internet References}

Althouse, P 1995: Wesleyan and Reformed Impulses in the Keswick and Pentecostal Movements. Available from: http://www.pneumafoundation. org/article.jsp?article=/Keswick-PAlthouse.xml [Accessed 30 November 2007].

Boardman, W E. A Higher Christian Life. Available from: http://online.aucnuc.ca/alliancestudies/boardman/Higher_tptc.htm [Accessed 30 November 2007]).

Combs, W W 2001. The disjunction between justification and sanctification in contemporary evangelical theology. Available from: http://www.dbts.edu/ journals/2001/Combs.pdf. [Accessed 30 November 2007].

Cunningham, R J 1974. From Holiness to Healing: The Faith Cure in America, 1872-1892. Available from: http://0www.jstor.org.oasis.unisa. ac.za. [Accessed 30 November 2007].

Hudson, N 2003. Early British Pentecostals and their relationship to health, healing and medicine. Available from: www.apts.edu/ajps/03-2/03-2NHudson.pdf. [Accessed 30 November 2007].

Murray, A. The Deeper Christian Life. Available from: www.ccel.org/ccel/ murray/ deeper.html. [Accessed 30 November 2007]

Murray, A. The Two Covenants. Available from: www.ccel.org/ccel/murray/ covenants.html. [Accessed 30 November 2007]. 